\title{
ANALIZA OPADÓW ATMOSFERYCZNYCH W UNIEJOWIE JAKO PRETEKST DO BADAŃ KLIMATU LOKALNEGO UZDROWISKA
}

Zarys treści: W artykule dokonano analizy statystycznej serii pomiarowej dobowych opadów atmosferycznych z lat 1980-2015, zarejestrowanych na stacji IMGW PIB w Uniejowie. Dla tej lokalizacji opracowano charakterystykę warunków opadowych w ujęciu wieloletnim, rocznym, sezonowym oraz miesięcznym. Opady atmosferyczne stanowią jeden z najbardziej zmiennych elementów pogody, nie tylko pod względem ilości (wysokości), ale również terminów ich występowania i czasu trwania, co wykazały przeprowadzone badania. Jednak głównym celem autorów było zwrócenie uwagi na zasadność prowadzenia systematycznych pomiarów meteorologicznych na terenie Uniejowa. Posiadanie wiedzy o sezonowej i wieloletniej cykliczności w występowaniu warunków pogodowych, jak również o możliwości pojawiania się znacznych odchyleń od wartości przeciętnych, wydaje się szczególnie wskazane w mieście, którego rozwój gospodarczy jest obecnie silnie uzależniony od napływu turystów ukierunkowanych na rekreację i rozrywkę na terenach otwartych. Ponadto jedynie dobre rozpoznanie specyficznych cech klimatu lokalnego uzdrowiska daje podstawy do jego ochrony przed skutkami narastającej w rejonie Uniejowa antropopresji.

Słowa kluczowe: Uniejów, uzdrowisko, opady atmosferyczne, warunki pogodowe, klimat lokalny

* Marcin Gorączko, dr, Uniwersytet Technologiczno-Przyrodniczy w Bydgoszczy, Katedra Ekoinżynierii i Fizykochemii Środowiska, Wydział Budownictwa, Architektury i Inżynierii Środowiska, 85-789 Bydgoszcz, ul. Prof. S. Kaliskiego 7, e-mail: gorgon@utp.edu.pl.

** Mateusz Cukras, mgr inż., Voessing Polska Sp. z o.o., 85-079 Bydgoszcz, ul. Kościuszki 53, e-mail: cmatic@onet.eu. 


\section{WSTĘP}

Na przestrzeni ostatnich kilkunastu lat pojawiło się wiele publikacji dotyczących obserwowanych współcześnie zmian w ilości opadów atmosferycznych na terenie Polski ${ }^{1}$. Większość autorów skłania się ku poglądowi, że dotychczasowe wyniki badań nie sugerują występowania trwałej, a przede wszystkim statystycznie istotnej, wieloletniej tendencji wzrostowej lub spadkowej w tym zakresie ${ }^{2}$. Nie wyklucza się jednak istnienia wieloletniego trendu zmian biorąc pod uwagę poszczególne sezony roku, jak na przykład wzrost ilości opadów wiosną i jesienią, przy jednoczesnym malejącym udziale opadów letnich w całkowitej rocznej sumie opadów ${ }^{3}$. Zjawisko to jest szczególnie często rozpatrywane pod kątem występowania suszy atmosferycznej i jej gospodarczych konsekwencji ${ }^{4}$. Inni autorzy stwierdzają z kolei zwiększającą się częstotliwość występowania intensywnych opadów deszczu. Zagadnienie to jest szczególnie wnikliwie analizowane na terenach zurbanizowanych, narażonych na podtopienia oraz tzw. powodzie miejskie, często o gwałtownym przebiegu, pociągające za sobą dotkliwe straty gospodarcze ${ }^{5}$. Wielu autorów widzi rozwiązanie tego narastającego wraz z postępami urbanizacji problemu, w radykalnej zmianie filozofii gospodarowania wodami opadowymi na ob-

1 B.M. Kaszewski, Zmiany klimatu Polski w pracach polskich klimatologów, „Przegląd Geofizyczny" 2015, nr 3-4, s. 222-227.

2 Np. T. Zawora, A. Ziernicka, Precipitation variability in time in Poland in the light of multi-annual mean values (1891-2000), „Studia Geograficzne” 2003, nr 75, „Acta Universitatis Wratislaviensis", nr 2542, s. 125; B.M. Kaszewski, Próba oceny zmian klimatu na Lubelszczyźnie $w$ drugiej połowie XX wieku, [w:] Klimatyczne aspekty środowiska geograficznego, red. J. Trepińska, Z. Olecki, IGiGP UJ 2006, s. 127-138; A. Ziernicka-Wojtaszek, Zmienność opadów atmosferycznych na obszarze Polski w latach 1971-2000, [w:] Klimatyczne aspekty środowiska geograficznego, IGiGP UJ, Kraków 2006; E. Żmudzka, Współczesne zmiany klimatu Polski, „Acta Agrophysica” 2009, nr 13(2) s. 565; G. Majewski, W. Przewoźniczuk, M. Kleniewska, Warunki opadowe na stacji meteorologicznej Ursynów SGGW w latach 1960-2009, „Przegląd Naukowy - Inżynieria i Kształtowanie Środowiska” 2010, nr 2 (48), s. 20, K. Szyga-Pluta, K. Grześkowiak, Warunki pluwialne w Poznaniu w latach 1981-2015, „Badania Fizjograficzne nad Polską Zachodnią" 2016, R. VII - Seria A - Geografia Fizyczna (A67), s. 241.

3 M. Czarnecka, J. Nidzgorska-Lencewicz, Wieloletnia zmienność sezonowych opadów w Polsce, „Woda - Środowisko - Obszary Wiejskie” 2012, t. 12, z. 2 (38), s. 58.

4 Np. K. Wójcik, W. Treder, A. Zbudniewek, Ocena przestrzennej zmienności występowania opadów atmosferycznych $w$ centralnej Polsce w latach 2013-2015, „Infrastruktura I Ekologia Terenów Wiejskich" 2016, nr I/1/2016, s. 73; L. Łabęcki, Agroclimatic determinants of irrigation needs, „Inżynieria Ekologiczna” 2016, nr 47, s. 199.

5 Np. M. Cebulska, R. Twardosz, Maksymalne opady dobowe w Krakowie w latach 1863 2015, [w:] L. Hejduk, E. Kaznowska (red.), Monografie Komitetu Gospodarki Wodnej PAN, 2016, 39, s. 7-17; P. Licznar, J. Rosa, Przyczyny i sposoby zapobiegania powodziom miejskim - nowoczesny warsztat inżyniera w praktyce, ,Przegląd Budowlany” 2017, nr 9, s. 34-35. 
szarach miast - poprzez tworzenie warunków do jej retencjonowania a nie jak dotąd jak najszybszego odprowadzenia ich poprzez sieć kanalizacyjną do odbiornika ${ }^{6}$.

Nie ulega zatem wątpliwości, że dążenie do rozpoznania współczesnych warunków opadowych, zarówno w odniesieniu do obszaru całego kraju, jak również prowadzone w skali regionalnej i lokalnej, cieszy się niesłabnącym zainteresowaniem badaczy reprezentujących zarówno nauki o Ziemi, nauki rolnicze, jak i nauki techniczne. Z pewnością ułatwiony obecnie dostęp do archiwalnych danych pomiarowych $\mathrm{IMGW} \mathrm{PIB}^{7}$ stanowi tu okoliczność sprzyjającą. Jednocześnie jednak istnieje na terenie Polski szereg lokalizacji, dla których nie opracowano dotychczas nawet ogólnej charakterystyki warunków opadowych, pomimo występowania w ich przypadku długich i jednorodnych ciągów pomiarowych, uzyskanych przez państwową służbę hydrologiczno-meteorologiczną. Takim miejscem jest właśnie miasto Uniejów.

W przypadku Uniejowa znaczenie zebranych danych pluwiograficznych jest o tyle większe niż gdzie indziej, że opady atmosferyczne są (a raczej do niedawna były, o czym będzie mowa na końcu pracy) jedynym systematycznie monitorowanym elementem pogody. W tej sytuacji nawet jeśli ich wystąpienie jedynie pośrednio wskazuje na zmienność ciśnienia atmosferycznego, zachmurzenia, temperatury powietrza i jego wilgotności czy kierunku, i prędkości wiatru, dane te stanowią bardzo cenne źródło informacji (jedyne uzyskiwane za pomocą pomiarów instrumentalnych) na temat lokalnych cech klimatu Uniejowa. Należy zwrócić uwagę, że warunkiem uzyskania i utrzymania statusu uzdrowiska w Polsce (o dowolnym profilu) jest posiadanie przez miejscowość klimatu o właściwościach leczniczych ${ }^{8}$. Dotyczy to więc również uzdrowiska w Uniejowie.

\section{MATERIAŁ I METODY}

Materiał źródłowy będący podstawą przeprowadzonej przez autorów analizy stanowiły dobowe sumy opadów atmosferycznych zmierzonych na stacji opadowej IMGW PIB w Uniejowie. Do końca 2015 roku funkcjonowała ona w zachodniej części miasta (N 515' 31', E $18^{\circ} 47^{\prime}$ 22”), na prawym brzegu rzeki Warty, przy

${ }^{6}$ Np. J. Królikowska, A. Królikowski, Wody opadowe: odprowadzanie, zagospodarowanie podczyszczanie $i$ wykorzystywanie, Seidel-Przywecki 2012, s. 12-14; A. Wałęga, A. Radecki-Pawlik, G. Kaczor, Naturalne sposoby zagospodarowania wód opadowych, Wyd. UR, Kraków 2016, s. 10-11.

${ }^{7}$ Dane Instytutu Meteorologii i Gospodarki Wodnej - Państwowego Instytutu Badawczego dostępne są za pośrednictwem systemu teleinformatycznego pod adresem: http://dane.imgw.pl. Za ich wykorzystanie do celów prywatnych nie są pobierane opłaty.

8 Ustawa z dnia 28 lipca 2005 r. o lecznictwie uzdrowiskowym, uzdrowiskach i obszarach ochrony uzdrowiskowej oraz gminach uzdrowiskowych (Dz.U. 2017, poz. 1056). 
ul. Kościelnickiej 19, na wysokości 110,2 m n.p.m (ryc. 1). Pomiary prowadzono tu przy użyciu deszczomierza Hellmana. W pracy uwzględniono nieprzerwany ciąg danych, zarejestrowanych na stacji opadowej w Uniejowie, od początku stycznia 1980 roku do końca grudnia 2015 roku9

Przy analizie danych pomiarowych wykorzystano powszechnie stosowane metody statystyczne, służące sporządzeniu podstawowych charakterystyk opadowych ${ }^{10}$. Określając częstość dni z opadem o określonej wysokości, zastosowano klasyfikację zaproponowaną przez Olechnowicz-Bobrowską ${ }^{11}$. Zawiera ona 5 klas, które odpowiadają określonym przedziałom dobowych sum opadów, tzn.:

- 0,1-1,0 mm - dzień z opadem bardzo słabym,

- 1,1-5,0 mm - dzień z opadem słabym,

- 5,1-10 mm - dzień z opadem umiarkowanie silnym,

- 10,1-20 mm - dzień z opadem silnym,

- powyżej $20 \mathrm{~mm}$ - dzień z opadem bardzo silnym.

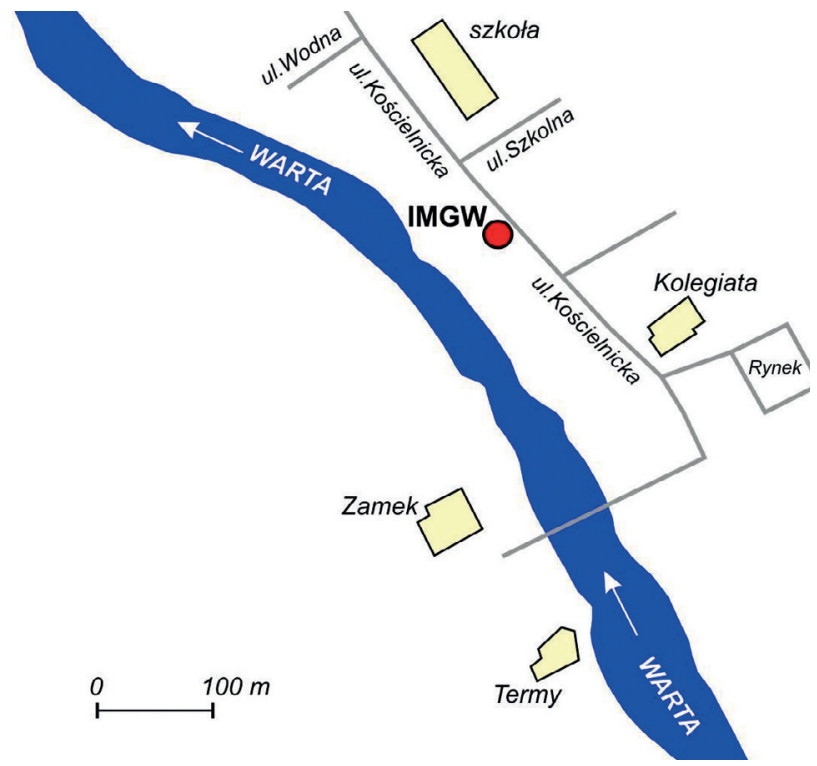

Ryc. 1. Lokalizacja stacji opadowej IMGW PIB w Uniejowie Źródło: opracowanie własne na podstawie www.google.com/maps

W pracy wykorzystano również jedną z najbardziej popularnych metod przeprowadzania analizy częstości powtarzania się lat z nadmiarem lub niedoborem

9 Dostępne dla Uniejowa dane pomiarowe w bazie IMGW PIB sięgają początku lat 50. XX wieku.

${ }^{10}$ Np. U. Kossowska-Cezak, D. Martyn, K. Olszewski, M. Kopacz-Lembowicz, Meteorologia i klimatologia. Pomiary, obserwacje, opracowania, Wydawnictwo Naukowe PWN, Warszawa-Lódź 2000.

${ }^{11}$ B. Olechnowicz-Bobrowska, Częstość dni z opadem w Polsce, „Prace Geograficzne” 1970, nr 86, s. 13. 
opadów ${ }^{12}$ zastosowaną przez Kaczorowską przy klasyfikacji warunków wilgotnościowych na terenie Polski ${ }^{13}$. Bazuje ona na relacji sumy opadów w określonym czasie (np. rok, sezon) do średniej sumy opadów z wielolecia, którą przyjmuje się za normę. Zgodnie z założeniami klasyfikacji:

- za rok (bądź porę roku) przeciętny uznaje taki w którym suma opadów zawiera się w granicach 90-110\% obliczonego opadu normalnego - odchylenie od średniej sumy wieloletniej jest nie większe niż $10 \%$,

- za rok suchy uznaje się taki, w którym suma opadów zawiera się w granicach 75-89\% obliczonego opadu normalnego, czyli niedobór sięga 11-25\%,

- za rok bardzo suchy uznaje się taki, w którym suma opadów zawiera się w granicach 50-74\% obliczonego opadu normalnego, czyli niedobór sięga $26-50 \%$,

- za rok skrajnie suchy uznaje się taki, w którym suma opadów wynosi poniżej $50 \%$ obliczonego opadu normalnego, czyli niedobór jest większy niż 50\%,

- za rok wilgotny uznaje się taki, w którym suma opadów zawiera się w granicach 111-125\% obliczonego opadu normalnego, czyli nadmiar sięga $11-25 \%$,

- za rok bardzo wilgotny uznaje się taki, w którym suma opadów zawiera się w granicach 126-150\% obliczonego opadu normalnego, czyli nadmiar sięga $26-50 \%$,

- za rok skrajnie wilgotny uznaje się taki, w którym suma opadów wynosi powyżej $150 \%$ obliczonego opadu normalnego, czyli nadmiar jest większy niż 50\%.

Oryginalna klasyfikacja Kaczorowskiej przeznaczona do oceny zmienności warunków opadowych w poszczególnych latach i porach roku, w ujęciu miesięcznym wymaga pewnej modyfikacji ${ }^{14}$. Wobec tego przyjęto, że:

- za miesiąc przeciętny uznaje się taki, w którym opad wynosił 75-125\% opadu normalnego,

- za miesiąc suchy uznaje się taki, w którym opad wynosił 50-74\% opadu normalnego,

- za miesiąc bardzo suchy uznaje się taki, w którym opad wynosił 25-49\% opadu normalnego,

- za miesiąc skrajnie suchy uznaje się taki, w którym opad wynosił poniżej $25 \%$ normy,

${ }^{12}$ E. Gąsiorek, E. Musiał, Porównanie i klasyfikacja warunków opadowych na podstawie wskaźnika standaryzowanego opadu i wskaźnika względnego opadu, „Woda - Środowisko - Obszary Wiejskie" 2011, t. 11, z. 4 (36), s. 107.

${ }^{13}$ Z. Kaczorowska, Opady w Polsce w przekroju wieloletnim, „Przegląd Geograficzny” 1962, nr 33, s. 72.

${ }^{14}$ Cz. Radomski, Agrometeorologia, PWN, Warszawa 1977; T. Tomaszewska, Susze atmosferyczne na przestrzeni ostatniego czterdziestolecia, Materiały Konferencji XXV Zjazd Agrometeorologów, Olsztyn-Mierki, 27-29.09.1994, Wyd. ART, Olsztyn 1994, s. 170-171. 
- za miesiąc wilgotny uznaje się taki, w którym opad wynosił $126-150 \%$ normy,

- za miesiąc bardzo wilgotny uznaje się taki, w którym opad wynosił $151-200 \%$ normy,

- za miesiąc skrajnie wilgotny uznaje się taki, w którym opad wynosił powyżej 200\% normy.

Podstawą do obliczenia opadu normalnego w niniejszej pracy były dobowe sumy opadów z okresu wielolecia 1980-2015.

\section{WYNIKI I ICH ANALIZA}

\section{Sumy roczne i sezonowe}

W badanym wieloleciu średnia roczna suma opadów wyniosła blisko $549 \mathrm{~mm}$. Najwyższe wartości (powyżej $700 \mathrm{~mm}$ ) notowane były trzykrotnie: w 1981 roku (713,8 mm), w 1999 roku $(752,2 \mathrm{~mm})$ oraz w roku 2010 (730,3 mm). Z kolei najniższe opady wystąpiły w 1989 roku (zaledwie $316,8 \mathrm{~mm}$ ).

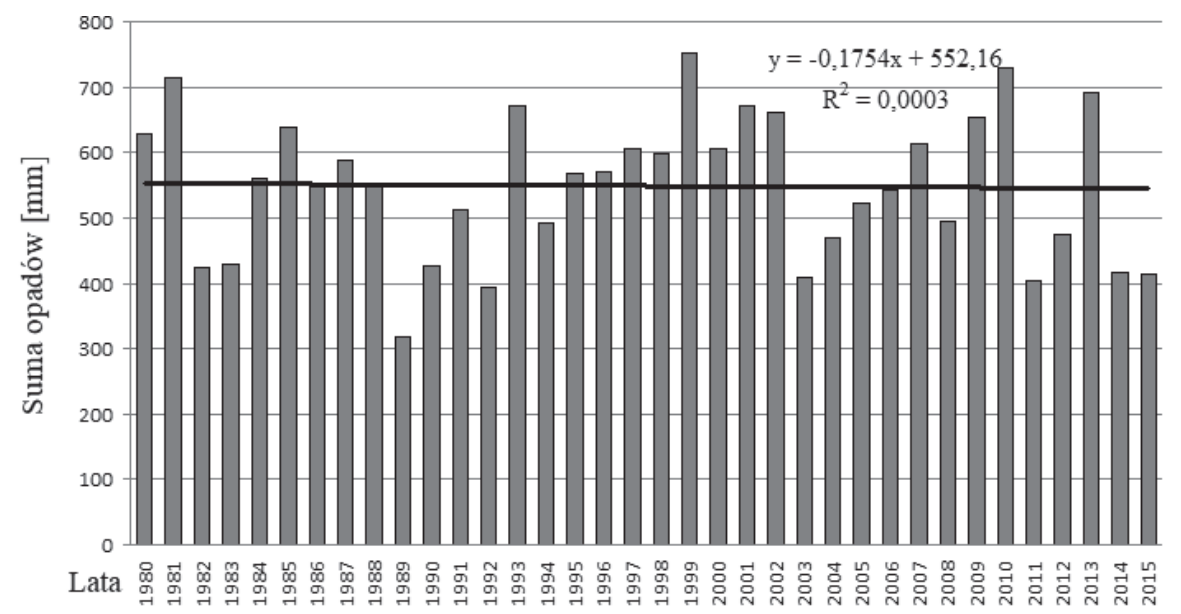

Ryc. 2. Roczne sumy opadów w Uniejowie (1980-2015)

Źródło: opracowanie własne na podstawie danych IMGW PIB

W wieloletnim przebiegu rocznych sum opadów w Uniejowie (ryc. 2) daje się zauważyć pewną prawidłowość - z roku na rok wysokość opadów wzrasta, przekraczając wartość przeciętną, aż do momentu kiedy następuje ich wyraźny (>200 mm) spadek. W analizowanym okresie stwierdzono występowanie trzech takich 7-10-letnich cykli. Ślad takiej powtarzalności jest również czytelny w przypadku chronologicznego zestawienia sum opadów dla półrocza ciepłego (ryc. 3). 
W rocznym przebiegu opadów wyraźnie dominują opady letnie (tab. 1). Stanowią one przeciętnie $37 \%$ sumy całkowitej, z pewną przewagą opadów w lipcu (14,5\% sumy rocznej). Opady czerwcowe mają mniejszy udział (przeciętnie $12,1 \%$ sumy rocznej), ale to właśnie w tym miesiącu odnotowano w Uniejowie najwyższą sumę miesięczną opadu (234,8 mm w 1999 roku). Najniższą wysokością opadów cechuje się luty (5,2\% sumy rocznej), kwiecień $(5,4 \%)$ oraz październik $(5,8 \%)$. Absolutne minimum (brak opadów) zanotowano w listopadzie (w 2011 roku).

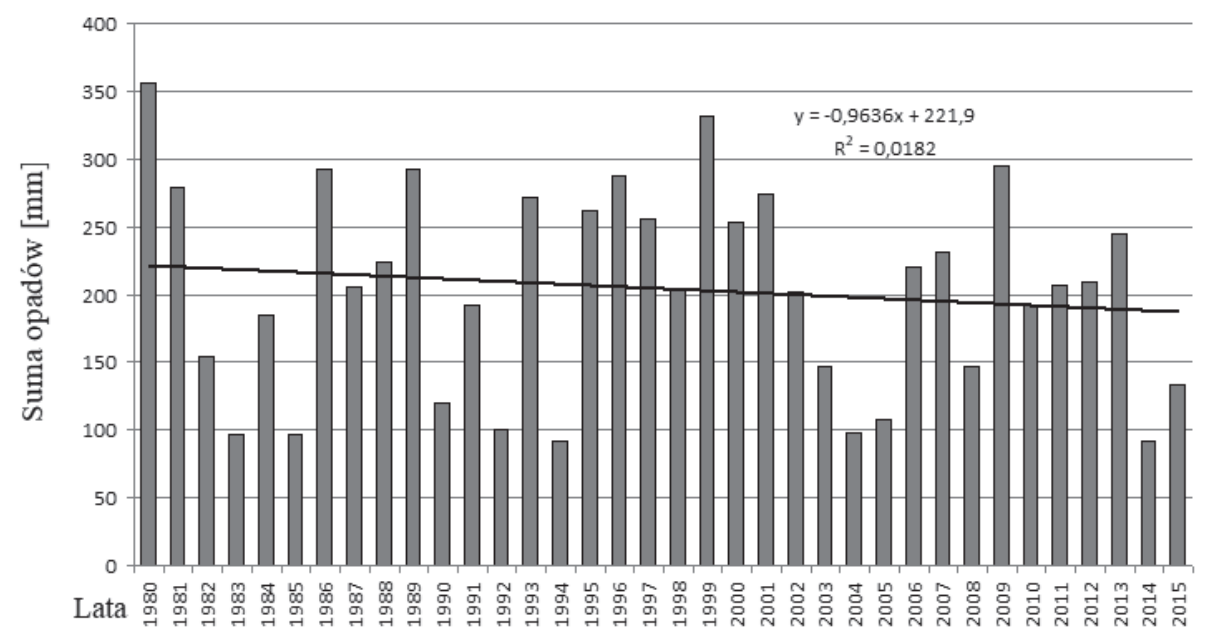

Ryc. 3. Sumy opadów w półroczu ciepłym (V-IX) w Uniejowie (1980-2015)

Źródło: opracowanie własne na podstawie danych IMGW PIB

\section{Sumy dobowe}

Zestawienie maksymalnych dobowych opadów w poszczególnych miesiącach roku w analizowanym wieloleciu umożliwia identyfikację typowych okresów występowania opadów o największej intensywności. Najwyższa dobowa suma opadów w ciągu roku notowana była w miesiącach od kwietnia do września (tab. 2), najczęściej jednak miało to miejsce w lipcu (10 przypadków) i w czerwcu (9 przypadków), rzadziej w maju (7 przypadków) i sierpniu (6 przypadków), a sporadycznie we wrześniu (3 przypadki) oraz w kwietniu (1 przypadek). Najwyższa dobowa suma opadów w Uniejowie, w rozpatrywanym okresie $(68,5 \mathrm{~mm})$ została zanotowana 28 czerwca 1999 roku.

W Uniejowie opady notowane są przeciętnie w ciągu 134 dni w roku, chociaż biorąc pod uwagę poszczególne lata, rozpiętość wartości jest dość znaczna (ryc. 4). O ile w 1981 roku oraz w roku 2004 liczba dni z opadem przekraczała 160, to zdarzało się, że wynosiła ona jedynie około 100 (lata 1989, 2011, 2014 i 2015). Wyjątkowy pod tym względem był rok 1982, w którym liczba dni z opadem atmosferycznym wyniosła 91 , a więc około $25 \%$ dni w roku. W ogólnej liczbie 


\begin{tabular}{|c|c|c|c|c|c|c|c|c|}
\hline \multirow{17}{*}{ 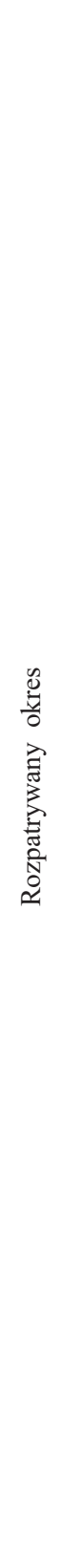 } & $\frac{y}{0}$ & $\begin{array}{l}\hat{\infty} \\
\text { 市 }\end{array}$ & $\begin{array}{l}\stackrel{0}{8} \\
\dot{8}\end{array}$ & $\begin{array}{l}0 \\
\infty \\
0\end{array}$ & $\begin{array}{l}\infty \\
\stackrel{\infty}{0} \\
\underbrace{\prime}\end{array}$ & $\begin{array}{l}\text { ñ } \\
\text { ñ }\end{array}$ & ત્ & $\begin{array}{l}\vec{\infty} \\
\text { m. }\end{array}$ \\
\hline & $\stackrel{\Xi}{\Xi}$ & $\hat{\tilde{\theta}}$ & $\begin{array}{l}\infty \\
\infty \\
\infty\end{array}$ & 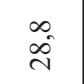 & $\frac{m}{n}$ & \begin{tabular}{c}
$m$ \\
\multirow{\infty}{0}{} \\
$\infty$
\end{tabular} & 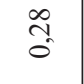 & $\begin{array}{l}n \\
\tilde{n} \\
\sim\end{array}$ \\
\hline & . & $\stackrel{2}{\partial}$ & $\hat{\vec{N}}$ & $\begin{array}{l}\vec{\nabla} \\
\vec{\nabla}\end{array}$ & $\begin{array}{l}0 \\
\dot{m}\end{array}$ & $\begin{array}{l}n \\
0 \\
0\end{array}$ & $\begin{array}{l}n \\
\text { ma } \\
0\end{array}$ & 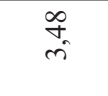 \\
\hline & 胥 & 犬̂. & $\frac{0}{\hat{m}}$ & $\begin{array}{l}0 \\
\text { i }\end{array}$ & $\stackrel{0}{a}$ & $\begin{array}{l}7 \\
\text { চn } \\
m\end{array}$ & $\begin{array}{l}0 \\
\text { ma } \\
0\end{array}$ & $\hat{i}$ \\
\hline & $\begin{array}{l}\frac{\pi}{\tilde{0}} \\
\stackrel{0}{0}\end{array}$ & 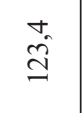 & $\begin{array}{l}n \\
\tilde{i}\end{array}$ & $\stackrel{\circ}{\stackrel{\gamma}{\gamma}}$ & $\begin{array}{l}\infty \\
\dot{f}\end{array}$ & $\stackrel{\circ}{\stackrel{\circ}{\sim}}$ & $\begin{array}{l}n \\
\tilde{m} \\
0\end{array}$ & $\begin{array}{l}\text { : } \\
\text { mi }\end{array}$ \\
\hline & $\overline{\bar{x}}$ & $\stackrel{\circ}{\circ}$ & $\stackrel{m}{r}$ & $\begin{array}{l}\infty \\
\tilde{\sim}\end{array}$ & $\hat{\infty}$ & $\overrightarrow{\tilde{\Xi}}$ & $\begin{array}{l}n \\
0 \\
0\end{array}$ & $\begin{array}{l}\vec{\infty} \\
i\end{array}$ \\
\hline & $\bar{x}$ & $\stackrel{r}{\circ}$ & $\stackrel{?}{r}$ & $\hat{\vec{\lambda}}$ & $\stackrel{0}{0}$ & $\begin{array}{l}n \\
n \\
n \\
n\end{array}$ & $\begin{array}{l}\infty \\
n \\
0 \\
0\end{array}$ & $\underset{\sim}{\stackrel{J}{n}}$ \\
\hline & $x$ & $\vec{n}$ & $\begin{array}{l}\infty \\
i\end{array}$ & $\stackrel{\nabla}{\Delta}$ & $\stackrel{\sim}{\sim}$ & $\vec{\varnothing}$ & $\begin{array}{l}\overrightarrow{6} \\
0\end{array}$ & $\begin{array}{l}\tilde{a} \\
\hat{n}\end{array}$ \\
\hline & ג & $\vec{f}$ & $\underset{\infty}{\infty}$ & $\overrightarrow{\text { si }}$ & $\overrightarrow{0}$ & $\stackrel{+}{\tilde{g}}$ & $\begin{array}{l}\mathbb{J} \\
0 \\
0\end{array}$ & $\begin{array}{l}\stackrel{2}{~} \\
\text { f }\end{array}$ \\
\hline & $\Xi$ & $\vec{n}$ & $\stackrel{\leftrightarrow}{\varrho}$ & $\begin{array}{l}\infty \\
\tilde{m}\end{array}$ & $\stackrel{\infty}{0}$ & $\begin{array}{l}n \\
\hat{0}\end{array}$ & $\begin{array}{l}\hat{\sigma} \\
0\end{array}$ & $\begin{array}{l}\hat{n} \\
\hat{n}\end{array}$ \\
\hline & $\bar{s}$ & $\stackrel{\nabla}{\curvearrowright}$ & $\begin{array}{l}n \\
\pm\end{array}$ & 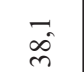 & $\underset{\substack{\sim \\
\sim}}{+}$ & $\begin{array}{l}\infty \\
\infty \\
\infty\end{array}$ & $\stackrel{\infty}{+}$ & స్ \\
\hline & 5 & $\begin{array}{l}n \\
8\end{array}$ & $\overrightarrow{\mathrm{I}}$ & $\begin{array}{l}\hat{b} \\
\dot{f}^{\prime}\end{array}$ & $\hat{n}_{0}$ & $\begin{array}{l}\infty \\
\stackrel{\infty}{N}\end{array}$ & $\vec{\sigma}$ & $\begin{array}{l}n \\
n\end{array}$ \\
\hline & $>$ & $\begin{array}{l}0 \\
8\end{array}$ & $\hat{\circ}$ & $\begin{array}{l}0 \\
\text { के }\end{array}$ & ?̧ & $\stackrel{\infty}{\hat{m}}$ & $\hat{n}$ & $\begin{array}{l}\tilde{n} \\
\text { nn }\end{array}$ \\
\hline & $\geq$ & $\ddot{\text { ते }}$ & $\ddot{n}$ & $\hat{a}$ & $\stackrel{2}{\sim}$ & $\stackrel{+}{\infty}$ & $\begin{array}{l}5 \\
0\end{array}$ & $\begin{array}{l}0 \\
\text { in } \\
i\end{array}$ \\
\hline & $\Xi$ & ले & ชู & ชู & $\stackrel{+}{\underset{f}{*}}$ & $\begin{array}{l}0 \\
\hat{\sigma}\end{array}$ & $\stackrel{\infty}{+}$ & $\stackrel{n}{i}$ \\
\hline & $=$ & $\underset{\infty}{\stackrel{+}{\sim}}$ & $\tilde{n}$ & $\hat{\mathrm{c}}$ & $\stackrel{\circ}{\sim}$ & $\begin{array}{l}\text { N } \\
\infty \\
\infty\end{array}$ & $\stackrel{n}{f}$ & $\begin{array}{c}\text { in } \\
i\end{array}$ \\
\hline & - & $\begin{array}{l}\infty \\
\dot{m}\end{array}$ & $\hat{\sigma}_{0}$ & $\begin{array}{l}0 \\
\infty \\
\infty\end{array}$ & $\vec{m}$ & $\stackrel{a}{\therefore}$ & ñ & $\underset{i}{\stackrel{J}{i}}$ \\
\hline \multicolumn{2}{|l|}{ 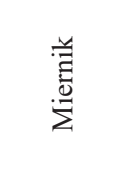 } & 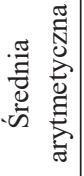 & 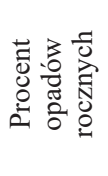 & 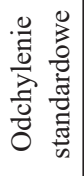 & 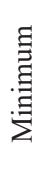 & 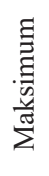 & 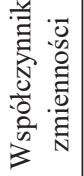 & 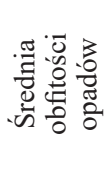 \\
\hline
\end{tabular}


dni z opadem wyraźnie przeważają dni z opadami słabymi (przedział wysokości $1,1-5,0 \mathrm{~mm}$, przeciętnie 64 dni w roku) oraz dni z opadami bardzo słabymi (przedział $0,1-1,0 \mathrm{~mm}, 37 \mathrm{dni})$. W tym drugim przypadku rozrzut wartości jest dość znaczny. Dotyczy to również zmienności z roku na rok (ryc. 5 i ryc. 6). W okresie 1980-2015 ich liczba kształtowała się od 58 w roku 2004 do poniżej 20 na początku drugiej dekady XXI w. Dni z opadem umiarkowanym (przedział 5,1-10,0 mm) średnio stanowią około $15 \%$ łącznej liczby dni w roku z opadem (ryc. 7).

Tabela 2. Maksymalne dobowe opady w poszczególnych miesiącach roku w Uniejowie (1980-2015)

\begin{tabular}{|r|r|r|r|r|r|r|r|r|r|r|r|r|}
\hline \multirow{2}{*}{ Rok } & \multicolumn{10}{|c|}{ Miesiące } \\
\cline { 2 - 14 } & \multicolumn{1}{|c|}{ I } & \multicolumn{1}{|c|}{ II } & \multicolumn{1}{|c|}{ III } & \multicolumn{1}{|c|}{ IV } & \multicolumn{1}{|c|}{ V } & VI & VII & VIII & IX & X & XI & XII \\
\hline 1980 & 3,3 & 9,0 & 5,8 & 26,5 & 6,2 & 29,8 & 19,6 & 24,6 & 16,6 & 9,5 & 8,2 & 8,0 \\
\hline 1981 & 11,5 & 4,0 & 24,2 & 4,6 & 11,8 & 17,1 & 27,7 & 27,5 & 23,0 & 25,1 & 7,6 & 15,2 \\
\hline 1982 & 13,6 & 4,5 & 6,8 & 6,9 & 34,3 & 18,6 & 14,0 & 22,4 & 5,9 & 3,5 & 8,0 & 6,0 \\
\hline 1983 & 10,1 & 19,9 & 6,0 & 6,1 & 9,6 & 21,5 & 15,3 & 20,2 & 14,1 & 7,6 & 6,2 & 6,1 \\
\hline 1984 & 7,6 & 3,9 & 18,0 & 3,7 & 22,6 & 12,2 & 12,2 & 36,8 & 34,4 & 4,0 & 12,6 & 4,8 \\
\hline 1985 & 4,6 & 4,6 & 7,5 & 11,2 & 32,3 & 12,0 & 12,2 & 56,4 & 8,2 & 5,2 & 8,6 & 8,3 \\
\hline 1986 & 10,5 & 8,7 & 8,1 & 10,0 & 25,3 & 32,8 & 14,9 & 18,2 & 11,0 & 9,1 & 9,3 & 12,6 \\
\hline 1987 & 8,9 & 4,1 & 3,7 & 8,0 & 17,6 & 19,8 & 11,6 & 12,2 & 28,6 & 12,2 & 20,5 & 9,5 \\
\hline 1988 & 11,3 & 9,9 & 11,3 & 4,4 & 12,2 & 11,2 & 26,3 & 44,3 & 16,2 & 3,6 & 14,3 & 8,0 \\
\hline 1989 & 4,8 & 3,0 & 2,9 & 12,1 & 6,2 & 18,4 & 13,5 & 7,6 & 3,3 & 7,2 & 11,1 & 11,1 \\
\hline 1990 & 7,7 & 7,0 & 2,9 & 18,4 & 8,6 & 6,8 & 19,1 & 6,4 & 17,1 & 16,2 & 9,5 & 11,6 \\
\hline 1991 & 2,7 & 4,0 & 14,9 & 7,4 & 23,3 & 36,2 & 16,2 & 16,2 & 12,5 & 4,2 & 14,5 & 13,0 \\
\hline 1992 & 7,1 & 6,2 & 17,1 & 3,5 & 8,2 & 5,4 & 12,4 & 6,4 & 19,4 & 10,2 & 6,4 & 14,6 \\
\hline 1993 & 9,0 & 7,5 & 15,1 & 5,6 & 9,4 & 33,0 & 37,4 & 11,8 & 32,1 & 10,7 & 6,0 & 13,2 \\
\hline 1994 & 21,0 & 2,8 & 9,2 & 15,6 & 23,6 & 5,8 & 16,0 & 10,3 & 9,0 & 14,0 & 7,4 & 6,7 \\
\hline 1995 & 5,7 & 6,2 & 7,7 & 7,4 & 16,5 & 28,1 & 28,1 & 28,8 & 17,5 & 5,8 & 14,5 & 7,0 \\
\hline 1996 & 12,5 & 9,8 & 5,6 & 6,6 & 17,5 & 23,4 & 43,2 & 33,9 & 39,0 & 6,0 & 7,7 & 4,3 \\
\hline 1997 & 1,5 & 8,8 & 5,5 & 7,5 & 33,0 & 17,8 & 58,4 & 11,4 & 11,4 & 15,7 & 21,5 & 6,6 \\
\hline 1998 & 22,5 & 7,7 & 6,5 & 7,7 & 16,4 & 16,7 & 21,7 & 16,6 & 23,2 & 11,2 & 17,8 & 20,6 \\
\hline 1999 & 7,6 & 10,7 & 12,5 & 26,3 & 11,6 & 68,5 & 33,0 & 7,0 & 7,0 & 8,9 & 8,6 & 5,4 \\
\hline 2000 & 7,6 & 8,9 & 17,5 & 12,0 & 22,0 & 4,5 & 36,7 & 18,3 & 10,2 & 7,2 & 13,8 & 15,1 \\
\hline 2001 & 3,8 & 6,1 & 6,2 & 21,2 & 14,8 & 33,0 & 26,5 & 16,0 & 17,0 & 5,0 & 9,9 & 6,0 \\
\hline 2002 & 7,1 & 9,8 & 8,5 & 7,0 & 39,5 & 29,6 & 35,4 & 5,9 & 29,1 & 24,5 & 9,5 & 2,7 \\
\hline 2003 & 9,0 & 3,0 & 4,1 & 4,6 & 16,2 & 4,4 & 29,2 & 17,1 & 6,3 & 10,0 & 5,5 & 18,0 \\
\hline
\end{tabular}




\begin{tabular}{|r|r|r|r|r|r|r|r|r|r|r|r|r|}
\hline \multirow{2}{*}{ Rok } & \multicolumn{10}{|c|}{ Miesiące } \\
\cline { 2 - 13 } & I & \multicolumn{1}{|c|}{ II } & \multicolumn{1}{|c|}{ III } & \multicolumn{1}{c|}{ IV } & \multicolumn{1}{|c|}{ V } & VI & VII & VIII & IX & X & XI & XII \\
\hline 2004 & 8,4 & 9,0 & 8,5 & 22,5 & 13,1 & 3,9 & 16,3 & 7,3 & 12,0 & 11,5 & 10,8 & 6,0 \\
\hline 2005 & 3,7 & 8,3 & 13,4 & 16,6 & 15,0 & 5,8 & 21,5 & 4,6 & 9,5 & 2,7 & 5,5 & 23,0 \\
\hline 2006 & 8,0 & 11,0 & 4,4 & 12,7 & 39,1 & 8,8 & 16,1 & 27,1 & 6,1 & 11,2 & 9,7 & 6,1 \\
\hline 2007 & 9,6 & 16,0 & 17,2 & 7,5 & 16,5 & 17,2 & 24,2 & 38,0 & 8,3 & 4,6 & 7,8 & 4,2 \\
\hline 2008 & 23,0 & 5,0 & 21,0 & 12,2 & 19,2 & 7,4 & 17,7 & 28,0 & 7,2 & 9,1 & 3,6 & 6,8 \\
\hline 2009 & 4,3 & 6,5 & 6,9 & 6,8 & 7,4 & 54,0 & 14,2 & 18,2 & 19,8 & 17,2 & 11,6 & 9,2 \\
\hline 2010 & 13,5 & 7,0 & 8,2 & 11,9 & 37,5 & 15,0 & 14,2 & 16,3 & 12,2 & 2,2 & 19,5 & 16,2 \\
\hline 2011 & 8,2 & 8,6 & 8,8 & 8,1 & 8,3 & 20,4 & 15,2 & 11,2 & 9,5 & 6,8 & 0 & 10,2 \\
\hline 2012 & 7,5 & 12,3 & 2,3 & 4,1 & 27,2 & 18,1 & 19,2 & 21,3 & 14,4 & 21,3 & 4,8 & 6,5 \\
\hline 2013 & 9,8 & 8,6 & 13,3 & 22,4 & 25,7 & 26,9 & 35,6 & 21,2 & 9,3 & 5,2 & 7,3 & 3,8 \\
\hline 2014 & 10,8 & 2,8 & 14,2 & 3,2 & 43,2 & 10,3 & 20,3 & 3,6 & 18,6 & 10,0 & 5,5 & 7,3 \\
\hline 2015 & 8,3 & 6,0 & 10,5 & 3,3 & 2,8 & 10,3 & 20,6 & 9,2 & 10,2 & 17,4 & 20,8 & 6,8 \\
\hline max & 23,0 & 19,9 & 24,2 & 26,5 & 43,2 & 68,5 & 58,4 & 56,4 & 39,0 & 25,1 & 21,5 & 23,0 \\
\hline
\end{tabular}

Źródło: opracowanie własne na podstawie danych IMGW PIB

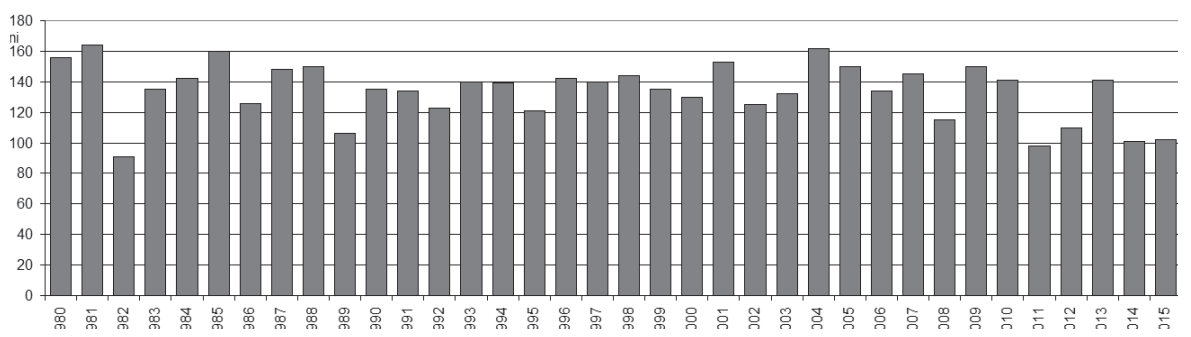

Ryc. 4. Liczba dni z opadem w Uniejowie (1980-2015)

Źródło: opracowanie własne na podstawie danych IMGW PIB

Dla oceny ryzyka wystąpienia na terenie Uniejowa opadów o dużej intensywności pożądane byłoby rejestrowanie chwilowego natężenia opadu. Wobec braku takich danych z konieczności przyjąć należy, że największe prawdopodobieństwo wystąpienia opadów o dużej intensywności występuje w dniach z opadem silnym (przedział 10,1-20 mm), a szczególnie podczas dni z opadem bardzo silnym (wysokość powyżej $20 \mathrm{~mm}$ ). W przypadku dni z opadem silnym (ryc. 8) ich liczba $\mathrm{w}$ rozpatrywanym wieloleciu nie przekraczała kilkunastu (maksymalnie 16 w 2010 roku), przeciętnie zaś stanowiła 7 dni. Zdecydowanie rzadziej notowano dni z opadem bardzo silnym, średnio $3 \mathrm{w}$ roku. Największa ich liczba (7 dni) wystąpiła w latach 1991, 2002 oraz 2013. Z kolei w latach 1989-1990 oraz w roku 1992 takich dni nie odnotowano (ryc. 9). 


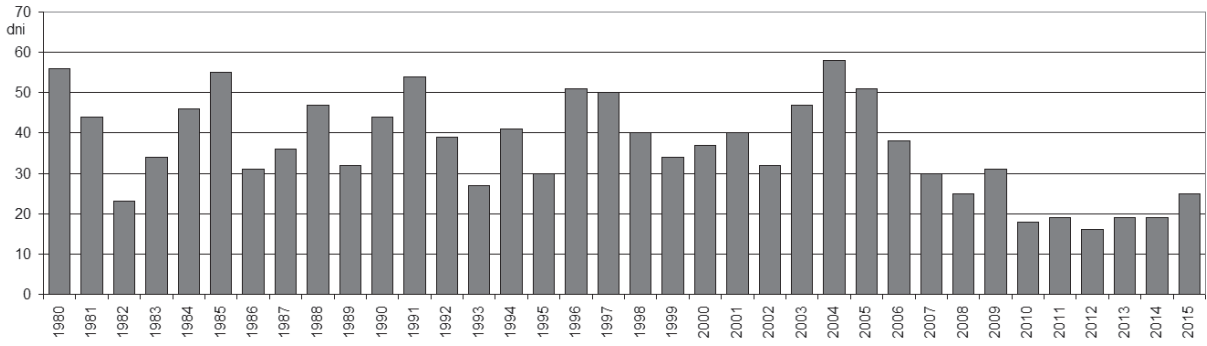

Ryc. 5. Liczba dni z opadem bardzo słabym na stacji Uniejów (1980-2015)

Źródło: opracowanie własne na podstawie danych IMGW PIB

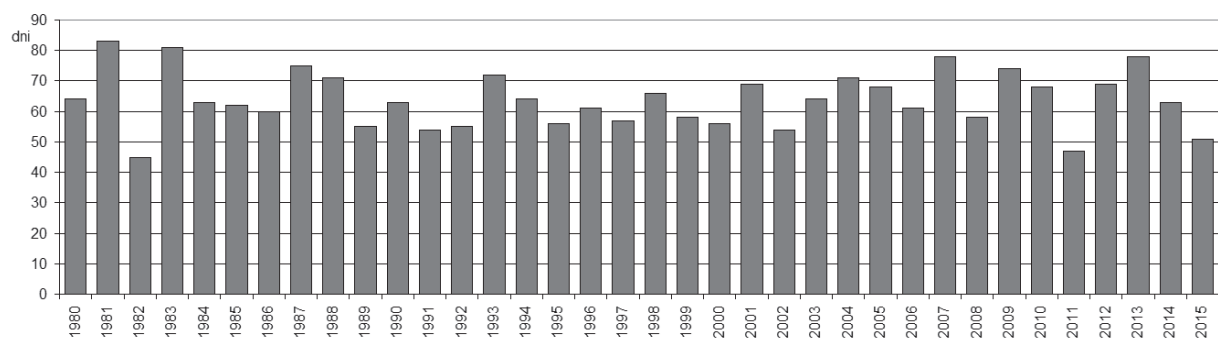

Ryc. 6. Liczba dni w roku z opadem słabym na stacji Uniejów w latach 1980-2015 Źródło: opracowanie własne na podstawie danych IMGW PIB

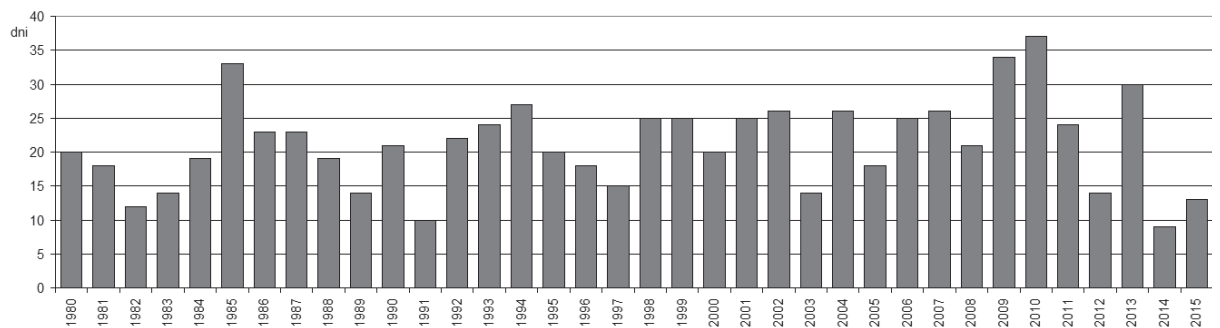

Ryc. 7. Liczba dni w roku z opadem umiarkowanie silnym na stacji Uniejów w latach 1980-2015 Źródło: opracowanie własne na podstawie danych IMGW PIB

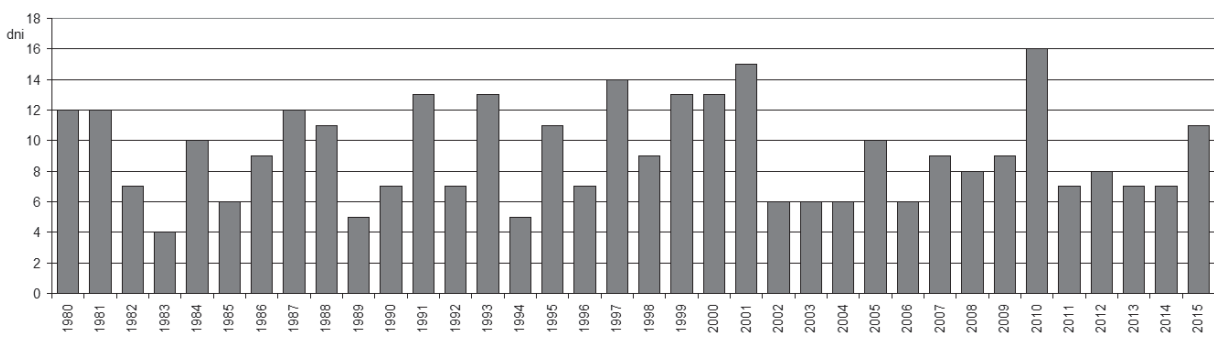

Ryc. 8. Liczba dni w roku z opadem silnym na stacji Uniejów w latach 1980-2015 Źródło: opracowanie własne na podstawie danych IMGW PIB 


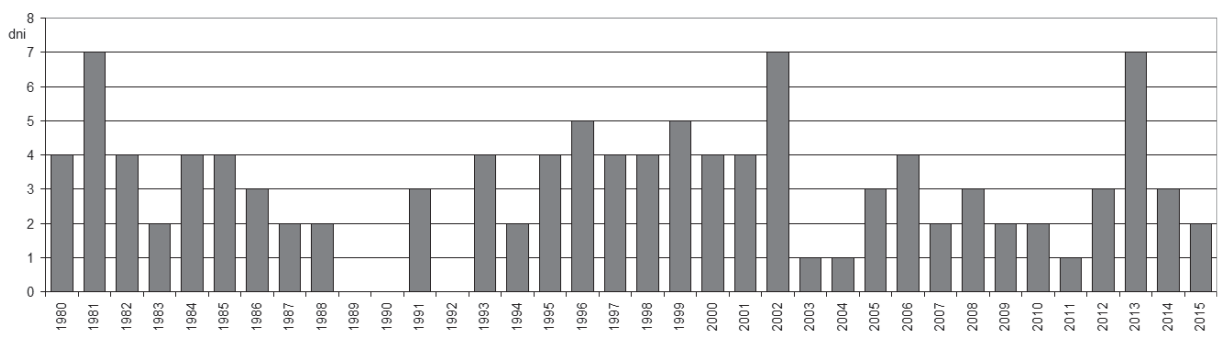

Ryc. 9. Liczba dni w roku z opadem bardzo silnym na stacji Uniejów w latach 1980-2015 Źródło: opracowanie własne na podstawie danych IMGW PIB

\section{Klasyfikacja warunków opadowyc}

Wyniki klasyfikacji warunków opadowych w poszczególnych latach w okresie 1980-2015, przeprowadzonej zgodnie z metodą Kaczorowskiej ${ }^{15}$ przedstawiono na ryc. 10. Ustalono, że w badanym wieloleciu w 13 przypadkach wystąpiły lata o przeciętnych warunkach wilgotnościowych, 9 lat suchych, 6 lat wilgotnych oraz po 4 przypadki lat bardzo suchych i bardzo wilgotnych. Nie zanotowano natomiast lat w których odchylenie od wartości referencyjnej (opad normalny z wielolecia) kwalifikowało by je do lat skrajnie suchych lub skrajnie wilgotnych. W przebiegu wartości daje się zauważyć pewną cykliczność, o wyraźnie zmiennym okresie.

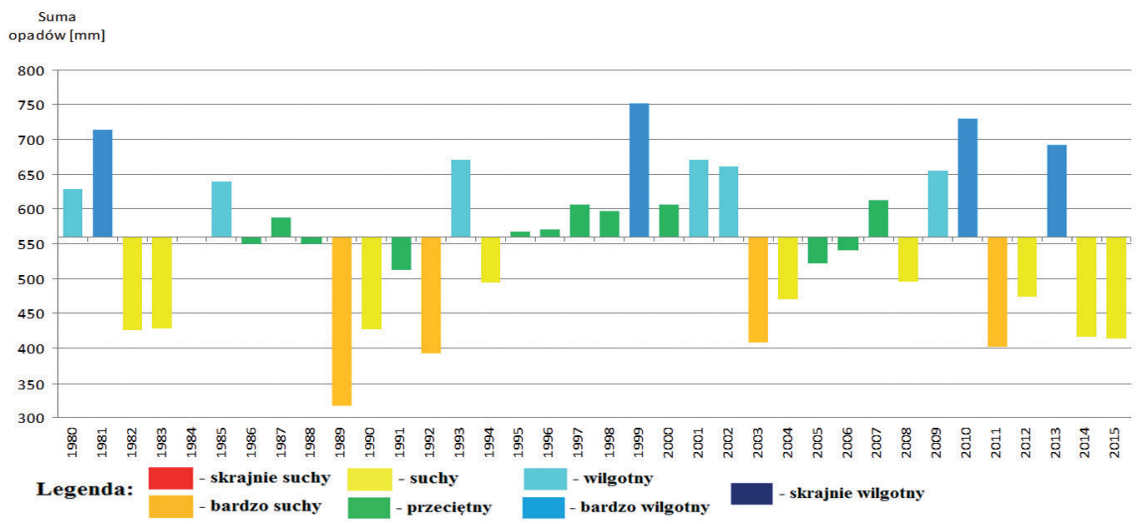

Ryc. 10. Klasyfikacja warunków opadowych w Uniejowie w latach 1980-2015 Źródło: opracowanie własne na podstawie danych IMGW PIB

Występowanie opadów w Uniejowie cechuje duża zmienność czasowa, co szczególnie ujawnia się, jeśli wziąć pod uwagę wyniki klasyfikacji warunków opadowych w ujęciu miesięcznym (tab. 3, ryc. 11-17).

${ }^{15}$ Z. Kaczorowska, Opady w Polsce w przekroju wieloletnim, „Przegląd Geograficzny” $1962, \mathrm{nr} 33$. 
Na łączną liczbę 432 miesięcy składających się na cały poddany analizie okres, $165 \mathrm{z}$ nich $(38 \%)$ cechowało się przeciętnymi warunkami wilgotnościowymi. Odchylenia od normy dotyczyły zdecydowanie częściej sytuacji, kiedy opady były niższe niż przeciętnie ( $37 \%$ liczby miesięcy, z czego miesiące suche stanowiły $18 \%$, miesiące bardzo suche $16 \%$ zaś miesiące skrajnie suche 3\%). W przypadku miesięcy bardziej mokrych niż przeciętnie (25\% łącznej liczby) miesiące wilgotne stanowiły $15 \%$, bardzo wilgotne $8 \%$, natomiast skrajnie wilgotne $6 \%$.

Tabela 3. Klasyfikacja warunków opadowych w Uniejowie

w ujęciu miesięcznym w latach 1980-2015

\begin{tabular}{|c|c|c|c|c|c|c|c|c|c|c|c|c|}
\hline \multirow{2}{*}{ Rok } & \multicolumn{12}{|c|}{ Miesiące } \\
\hline & I & II & III & IV & $\mathrm{V}$ & VI & VII & VIII & IX & $\mathrm{X}$ & XI & XII \\
\hline 1980 & $\mathrm{~s}$ & $\mathrm{p}$ & $\mathrm{s}$ & bw & ss & sw & bw & $\mathrm{p}$ & $\mathrm{p}$ & bw & $\mathrm{s}$ & $\mathrm{s}$ \\
\hline 1981 & $\mathrm{w}$ & $\mathrm{p}$ & $\mathrm{w}$ & bs & $\mathrm{p}$ & $\mathrm{w}$ & $\mathrm{w}$ & $\mathrm{w}$ & $\mathrm{p}$ & SW & w & SW \\
\hline 1982 & $\mathrm{p}$ & bs & bs & $\mathrm{p}$ & bw & $\mathrm{p}$ & bs & $\mathrm{p}$ & ss & ss & bs & $\mathrm{s}$ \\
\hline 1983 & bw & bw & $\mathrm{p}$ & $\mathrm{s}$ & $\mathrm{p}$ & bs & bs & $\mathrm{s}$ & $\mathrm{s}$ & $\mathrm{p}$ & $\mathrm{p}$ & $\mathrm{s}$ \\
\hline 1984 & $\mathrm{p}$ & $\mathrm{s}$ & $\mathrm{p}$ & bs & $\mathrm{p}$ & $\mathrm{p}$ & $\mathrm{p}$ & $\mathrm{p}$ & sw & $\mathrm{s}$ & $\mathrm{p}$ & bs \\
\hline 1985 & $\mathrm{~s}$ & $\mathrm{p}$ & $\mathrm{s}$ & $\mathrm{p}$ & w & $\mathrm{p}$ & $\mathrm{s}$ & sw & $\mathrm{p}$ & bs & $\mathrm{s}$ & bw \\
\hline 1986 & W & $\mathrm{s}$ & $\mathrm{p}$ & $\mathrm{s}$ & $\mathrm{p}$ & $\mathrm{p}$ & $\mathrm{s}$ & w & $\mathrm{p}$ & $\mathrm{p}$ & $\mathrm{s}$ & bw \\
\hline 1987 & W & $\mathrm{p}$ & bs & $\mathrm{s}$ & $\mathrm{s}$ & w & $\mathrm{p}$ & $\mathrm{p}$ & bw & $\mathrm{S}$ & bw & $\mathrm{p}$ \\
\hline 1988 & $\mathrm{p}$ & $\mathrm{p}$ & w & bs & $\mathrm{s}$ & $\mathrm{p}$ & $\mathrm{w}$ & $\mathrm{w}$ & $\mathrm{p}$ & bs & $\mathrm{p}$ & $\mathrm{w}$ \\
\hline 1989 & bs & $\mathrm{s}$ & bs & $\mathrm{p}$ & bs & $\mathrm{s}$ & $\mathrm{s}$ & bs & ss & $\mathrm{p}$ & $\mathrm{p}$ & $\mathrm{p}$ \\
\hline 1990 & $\mathrm{~s}$ & $\mathrm{p}$ & bs & $\mathrm{w}$ & ss & $\mathrm{s}$ & $\mathrm{s}$ & bs & bw & $\mathrm{p}$ & $\mathrm{p}$ & $\mathrm{p}$ \\
\hline 1991 & bs & bs & $\mathrm{p}$ & $\mathrm{p}$ & w & $\mathrm{W}$ & $\mathrm{s}$ & $\mathrm{p}$ & $\mathrm{s}$ & bs & W & $\mathrm{p}$ \\
\hline 1992 & bs & $\mathrm{p}$ & bw & $\mathrm{s}$ & bs & bs & $\mathrm{s}$ & bs & $\mathrm{p}$ & $\mathrm{p}$ & $\mathrm{p}$ & $\mathrm{p}$ \\
\hline 1993 & $\mathrm{p}$ & $\mathrm{p}$ & $\mathrm{p}$ & bs & $\mathrm{s}$ & W & bw & $\mathrm{p}$ & SW & $\mathrm{p}$ & $\mathrm{s}$ & bw \\
\hline 1994 & w & bs & bw & SW & $\mathrm{p}$ & bs & bs & $\mathrm{p}$ & $\mathrm{p}$ & $\mathrm{p}$ & $\mathrm{s}$ & $\mathrm{w}$ \\
\hline 1995 & $\mathrm{p}$ & $\mathrm{p}$ & $\mathrm{p}$ & $\mathrm{p}$ & $\mathrm{s}$ & w & $\mathrm{p}$ & bw & bw & $\mathrm{s}$ & $\mathrm{s}$ & bs \\
\hline 1996 & $S$ & $\mathrm{p}$ & $\mathrm{S}$ & $\mathrm{p}$ & $\mathrm{p}$ & $\mathrm{p}$ & bw & w & bw & $\mathrm{S}$ & bs & SS \\
\hline 1997 & SS & $\mathrm{p}$ & $\mathrm{s}$ & $\mathrm{p}$ & bw & $\mathrm{p}$ & sw & bs & $\mathrm{s}$ & W & W & $\mathrm{p}$ \\
\hline 1998 & W & $\mathrm{p}$ & $\mathrm{p}$ & $\mathrm{p}$ & $\mathrm{s}$ & $\mathrm{p}$ & $p$ & $\mathrm{p}$ & $\mathrm{p}$ & SW & $\mathrm{p}$ & $\mathrm{p}$ \\
\hline 1999 & $p$ & bw & $\mathrm{w}$ & SW & $\mathrm{p}$ & sw & $\mathrm{p}$ & $p$ & bs & bw & SS & $\mathrm{s}$ \\
\hline 2000 & $\mathrm{p}$ & w & bw & bs & $\mathrm{p}$ & bs & SW & $\mathrm{p}$ & $\mathrm{s}$ & $\mathrm{s}$ & $\mathrm{p}$ & $\mathrm{p}$ \\
\hline 2001 & bs & $\mathrm{p}$ & $\mathrm{p}$ & SW & $\mathrm{p}$ & bw & $\mathrm{w}$ & $\mathrm{p}$ & SW & $\mathrm{s}$ & $\mathrm{p}$ & $\mathrm{p}$ \\
\hline
\end{tabular}




\begin{tabular}{|c|c|c|c|c|c|c|c|c|c|c|c|c|}
\hline \multirow{2}{*}{ Rok } & \multicolumn{12}{|c|}{ Miesiące } \\
\hline & I & II & III & IV & V & VI & VII & VIII & IX & $X$ & XI & XII \\
\hline 2002 & $\mathrm{p}$ & SW & $\mathrm{p}$ & bs & SW & w & $\mathrm{p}$ & bs & $\mathrm{p}$ & SW & $\mathrm{p}$ & SS \\
\hline 2003 & $\mathrm{p}$ & bs & bs & $\mathrm{s}$ & $\mathrm{p}$ & bs & $\mathrm{p}$ & $\mathrm{p}$ & bs & w & $\mathrm{s}$ & $\mathrm{p}$ \\
\hline 2004 & w & $\mathrm{w}$ & $\mathrm{p}$ & $\mathrm{p}$ & $\mathrm{p}$ & bs & bs & $\mathrm{s}$ & s & $\mathrm{p}$ & $\mathrm{w}$ & bs \\
\hline 2005 & $\mathrm{~s}$ & w & $\mathrm{p}$ & $\mathrm{p}$ & bw & bs & $\mathrm{p}$ & bs & $\mathrm{s}$ & bs & $\mathrm{s}$ & sw \\
\hline 2006 & $\mathrm{p}$ & w & $\mathrm{S}$ & w & bw & bs & bs & SW & bs & $\mathrm{p}$ & $\mathrm{p}$ & $\mathrm{s}$ \\
\hline 2007 & SW & bw & w & $\mathrm{s}$ & $\mathrm{p}$ & $\mathrm{p}$ & $\mathrm{w}$ & $\mathrm{p}$ & s & $\mathrm{p}$ & $\mathrm{p}$ & bs \\
\hline 2008 & sw & $\mathrm{p}$ & bw & $\mathrm{p}$ & $\mathrm{S}$ & bs & $\mathrm{S}$ & $\mathrm{p}$ & s & $\mathrm{p}$ & bs & $\mathrm{s}$ \\
\hline 2009 & $\mathrm{~s}$ & $\mathrm{p}$ & w & bs & $\mathrm{s}$ & SW & $\mathrm{p}$ & $\mathrm{p}$ & $\mathrm{p}$ & SW & $\mathrm{p}$ & $\mathrm{p}$ \\
\hline 2010 & bw & $\mathrm{p}$ & $\mathrm{p}$ & $\mathrm{p}$ & sw & $\mathrm{S}$ & $\mathrm{p}$ & W & $\mathrm{p}$ & SS & SW & $\mathrm{p}$ \\
\hline 2011 & $\mathrm{p}$ & $\mathrm{p}$ & $\mathrm{S}$ & $\mathrm{S}$ & bs & $\mathrm{p}$ & w & $\mathrm{S}$ & bs & $\mathrm{S}$ & SS & $\mathrm{p}$ \\
\hline 2012 & w & w & SS & bs & $\mathrm{p}$ & w & $\mathrm{p}$ & $\mathrm{p}$ & $\mathrm{p}$ & $\mathrm{p}$ & $\mathrm{s}$ & $\mathrm{s}$ \\
\hline 2013 & sw & $\mathrm{p}$ & bw & bw & bw & bw & $\mathrm{p}$ & $\mathrm{p}$ & bw & $\mathrm{s}$ & $\mathrm{p}$ & bs \\
\hline 2014 & $\mathrm{p}$ & bs & $\mathrm{p}$ & bs & sw & bs & $\mathrm{s}$ & bs & $\mathrm{p}$ & $p$ & bs & $\mathrm{p}$ \\
\hline 2015 & $\mathrm{p}$ & bs & $\mathrm{p}$ & bs & SS & bs & $\mathrm{p}$ & SS & $\mathrm{s}$ & bw & SW & $\mathrm{s}$ \\
\hline
\end{tabular}

Objaśnienia symboli: ss - miesiąc skrajnie suchy; bs - miesiąc bardzo suchy; $\mathrm{s}$ - miesiąc suchy; $\mathrm{p}$ - miesiąc przeciętny; $\mathrm{w}$ - miesiąc wilgotny; bw - miesiąc bardzo wilgotny; sw - miesiąc skrajnie wilgotny

Źródło: opracowanie własne na podstawie danych IMGW PIB

Biorąc pod uwagę cały okres obserwacji (lata 1980-2015) w Uniejowie najbardziej wilgotnymi miesiącami były: maj (trzykrotnie uznany za skrajnie wilgotny i pięciokrotne za bardzo wilgotny), wrzesień (trzykrotnie skrajnie wilgotny oraz pięciokrotnie bardzo wilgotny) i październik (czterokrotnie skrajnie wilgotny i trzykrotnie bardzo wilgotny). Marzec był jedynym miesiącem w roku, w którym nie odnotowano warunków skrajnie wilgotnych. Z kolei ekstremalny deficyt opadów ani razu nie wystąpił w przypadku lutego, kwietnia, czerwca i lipca. Dużą zmiennością charakteryzuje się nawet udział miesięcy o przeciętnej wilgotności, który tylko dla półrocza ciepłego kształtował się od $28 \%$ dla maja do $47 \% \mathrm{w}$ przypadku sierpnia (ryc. 11 ).

Rozpatrując warunki opadowe w tych samych miesiącach rok po roku, są one bardziej stabilne w przypadku deficytu opadów w stosunku do wartości przeciętnych. Natomiast występowanie miesięcy wilgotnych, bardzo wilgotnych, a zwłaszcza skrajnie wilgotnych charakteryzuje się większą zmiennością. Na przykład od początku XXI w. zwiększyła się ilość opadów w maju (ryc. 12). Nie ma 
jednak podstaw, aby uznać fakt ten za przejaw stałego trendu. Podobna sytuacja (dwa lata skrajnie wilgotne i jeden rok bardzo wilgotny) wystąpiła w przypadku opadów lipcowych pod koniec XX w. (ryc. 14). W kolejnych latach miesiąc ten pod względem warunków wilgotnościowych na ogół nie wykraczał poza normę Z wielolecia. Niewątpliwie jednak począwszy od końca XX w. wzrosła częstość występowania miesięcy skrajnie wilgotnych. Dotyczy to zwłaszcza stycznia, maja, października oraz listopada. Z kolei w ostatnich dwóch dekadach czerwiec oraz kwiecień okazywały się, częściej niż wcześniej, miesiącami bardzo suchymi.

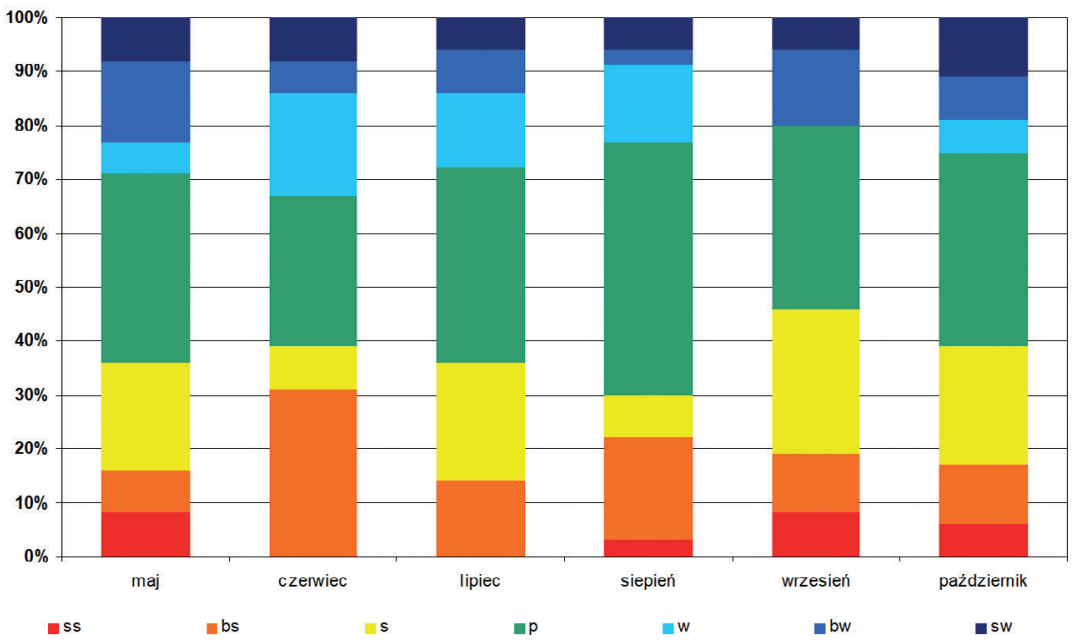

Ryc. 11. Udział poszczególnych klas wilgotności miesięcy w półroczu ciepłym w Uniejowie Objaśnienia symboli jak dla Tabeli 3 Źródło: opracowanie własne na podstawie danych IMGW PIB

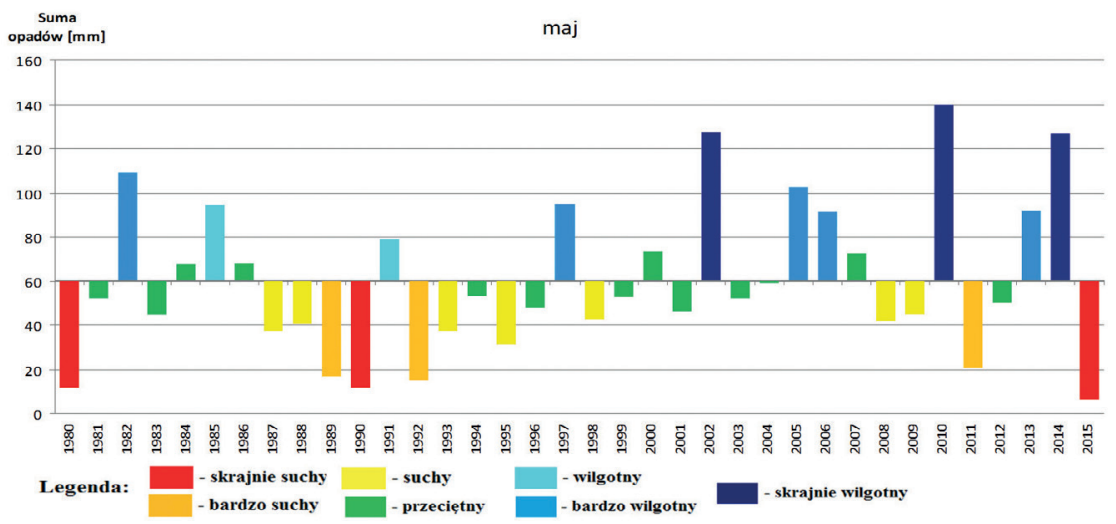

Ryc. 12. Klasyfikacja warunków opadowych w Uniejowie dla maja (lata 1980-2015) Źródło: opracowanie własne na podstawie danych IMGW PIB 


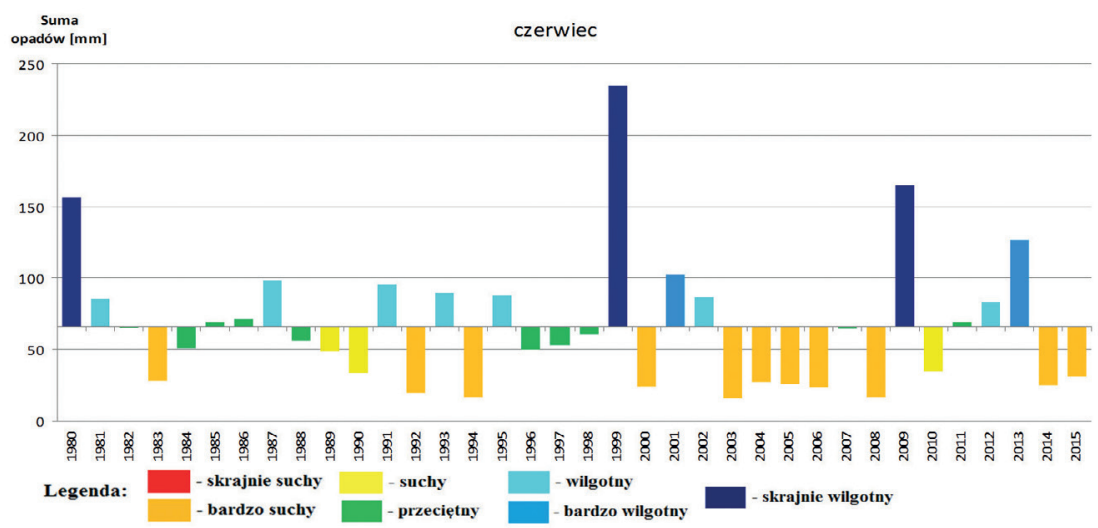

Ryc. 13. Klasyfikacja warunków opadowych w Uniejowie dla czerwca (lata 1980-2015) Źródło: opracowanie własne na podstawie danych IMGW PIB

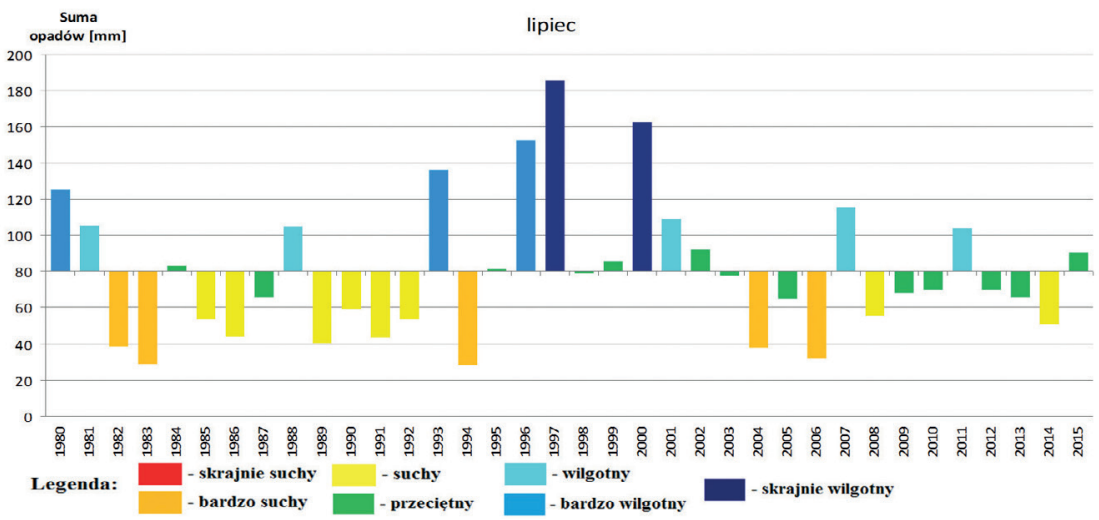

Ryc. 14. Klasyfikacja warunków opadowych w Uniejowie dla lipca (lata 1980-2015) Źródło: opracowanie własne na podstawie danych IMGW PIB

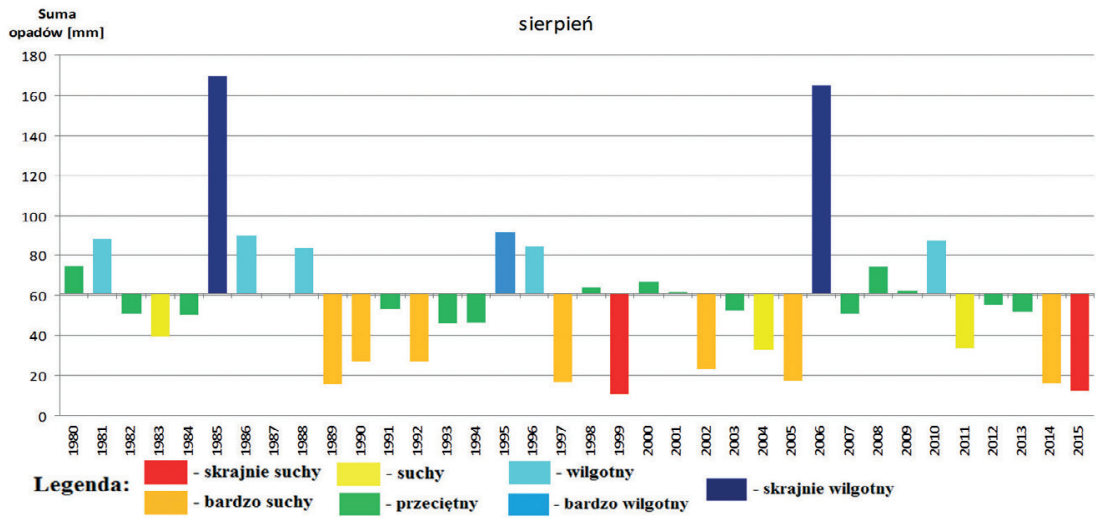

Ryc. 15. Klasyfikacja warunków opadowych w Uniejowie dla sierpnia (lata 1980-2015) Źródło: opracowanie własne na podstawie danych IMGW PIB 


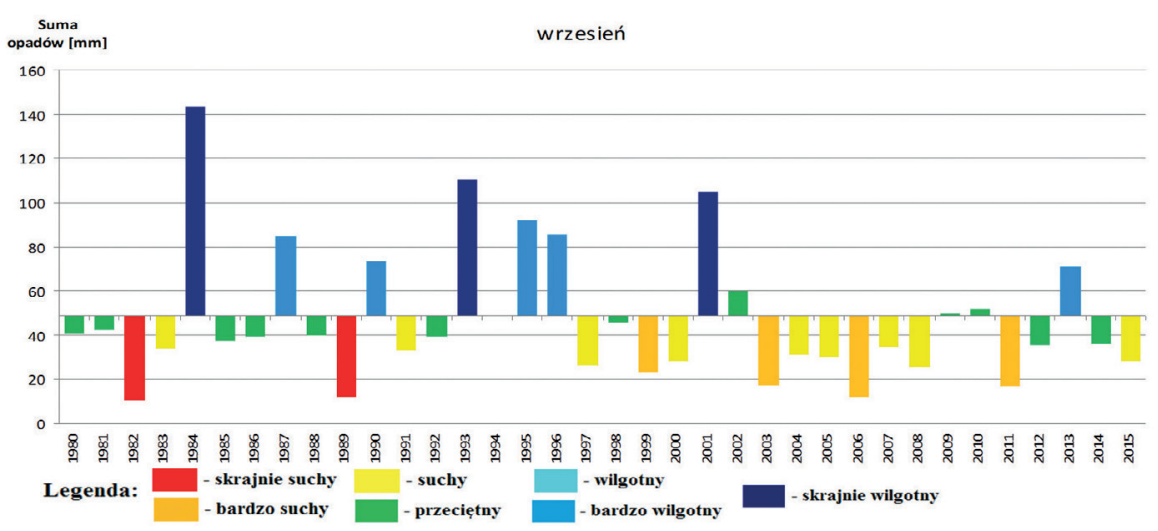

Ryc. 16. Klasyfikacja warunków opadowych w Uniejowie dla września (lata 1980-2015) Źródło: opracowanie własne na podstawie danych IMGW PIB

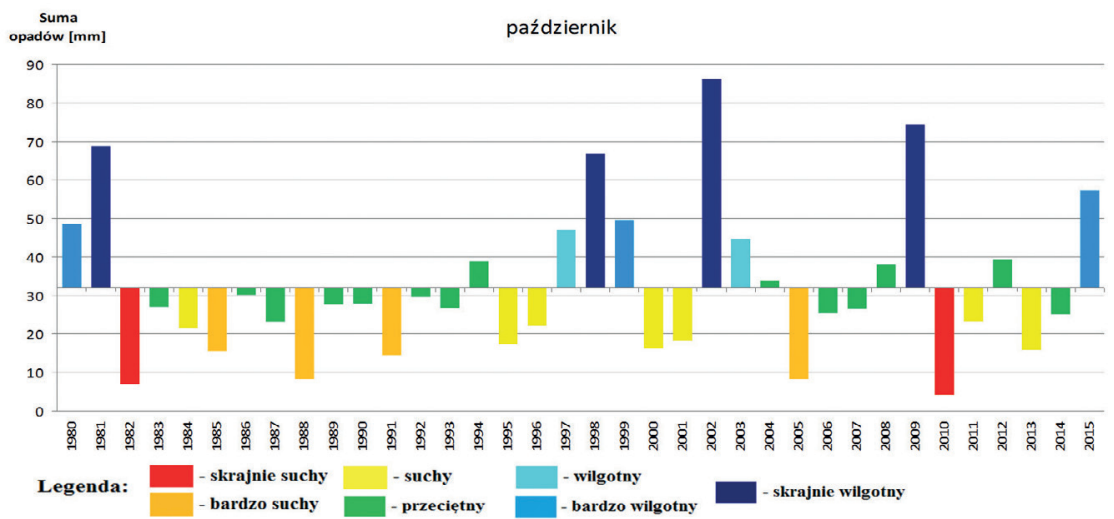

Ryc. 17. Klasyfikacja warunków opadowych w Uniejowie dla października (lata 1980-2015) Źródło: opracowanie własne na podstawie danych IMGW PIB

\section{WNIOSKI}

Przedstawiona powyżej analiza warunków opadowych na terenie Uniejowa oczywiście nie wyczerpuje zagadnienia. W gruncie rzeczy stanowi ona wstęp i zachętę do sporządzenia bardziej szczegółowej i wieloaspektowej charakterystyki. Taką możliwość przecież daje długi, bo sięgający lat 50. XX w. ciąg pomiarowy. $\mathrm{Z}$ niewiadomych przyczyn nie doczekał się on dotychczas opracowania, zaś warunki wilgotnościowe w obrębie miasta wcześniej były charakteryzowane jedynie na podstawie innych, dość odległych od Uniejowa stacji meteorologicz- 
nych, położonych w Poddębicach, a nawet w Kole ${ }^{16}$. Tymczasem, jak wynika z przeprowadzonych analiz porównawczych w obrębie Kotliny Kolskiej i jej bezpośredniego otoczenia ${ }^{17}$, zastosowanie metody analogii w przypadku tak przestrzennie zmiennego elementu, jakim jest opad, nie powinno być rekomendowane dla lokalizacji, dla których nie jest to konieczne, ze względu na brak miejscowego materiału pomiarowo-obserwacyjnego. Odnosi się to więc do gminy Uniejów, a zwłaszcza do samego miasta.

$\mathrm{Z}$ dniem 31 grudnia 2015 roku, po kilkudziesięciu latach funkcjonowania, stacja opadowa w Uniejowie, wchodząca w skład państwowej sieci hydrologiczno-meteorologicznej, zaprzestała swojej działalności a będące na jej wyposażeniu instrumenty pomiarowe zostały zdemontowane. Ostatni opad dobowy zanotowano tutaj w dniu 28 grudnia 2015 roku (wyniósł on $0,5 \mathrm{~mm}$ ). Fakt ten wydaje się dość zaskakujący w przypadku miasta, które raptem kilka lat temu uzyskało status uzdrowiska. Jedną z ważniejszych (przynajmniej formalnie) przesłanek do jego nadania były korzystne dla kuracjuszy cechy mikroklimatu, a ściślej mówiąc występowanie tutaj klimatu leczniczego ${ }^{18}$. Wydawać by się więc mogło, że w miarę rozwoju uzdrowiska będą pojawiały się nowe narzędzia, służące rejestracji elementów pogody, z których dane będzie można wykorzystać w celu badania i ochrony lokalnego klimatu. Współcześnie na świecie i w Polsce mamy do czynienia z dynamicznym postępem technologicznym w zakresie miernictwa meteorologicznego. Zmierza on w kierunku pełnej automatyzacji pomiarów, przy jednoczesnym zachowaniu standardów Światowej Organizacji Meteorologicznej ${ }^{19}$. W tych okolicznościach, w wielu miejscowościach w kraju, podejmowana jest decyzja o tworzeniu własnych, utrzymywanych przez samorząd lokalny, bezobsługowych, wieloparametrowych stacji meteorologicznych, często w miejsce zlikwidowanych stacji IMGW PIB lub jako ich uzupełnienie. Wydaje się, że realizacja takiego przedsięwzięcia w przypadku Uniejowa jest szczególnie uzasadniona, doskonale wpisując się w strategię rozwoju uzdrowiska.

W strukturze użytkowania gruntów w Uniejowie użytki rolne zajmują blisko $50 \%$ powierzchni miasta ${ }^{20}$. Jednak konieczność posiadania dobrego rozpoznania

${ }^{16}$ K. Błażejczyk, J. Szmyd, A.B. Adamczyk, Ogólne cechy potencjału leczniczego klimatu i bioklimatu Uniejowa, „Biuletyn Uniejowski” 2012, t. 1, s. 49-50.

${ }^{17}$ M. Cukras, Analiza zmienności opadów atmosferycznych w rejonie Uniejowa i Poddębic (woj. łódzkie), praca mgr, PD_11332_1_SD-IS-12_99405, APD UTP, Bydgoszcz 2017; Ł. Dąbrowski, Analiza zmienności opadów atmosferycznych w rejonie Kola i Kłodawy (woj. wielkopolskie), praca mgr, PD 11333 1 SD-IS-12 99407, APD UTP, Bydgoszcz 2017.

${ }_{18}$ Z. Cieślukowski, W. Karpiński, Operat uzdrowiskowy - Uzdrowisko Uniejów, Fundacja Uzdrowiska, Warszawa 2011, s. 142.

${ }^{19}$ Guide to Meteorological Instruments and Methods of Observation (WMO - No. 8, the CIMO Guide) 2014 edition.

${ }^{20}$ Bank Danych Lokalnych, Główny Urząd Statystyczny, www.bdl.stat.gov.pl [dostęp: 20.04.2018]. 
lokalnej specyfiki występowania opadów atmosferycznych i ich wieloletniej oraz sezonowej zmienności wynika dziś bardziej z pozarolniczych kierunków jego rozwoju gospodarczego, zachodzącego głównie w sektorze usług turystycznych. W Uniejowie aktywność turystów wyraźnie skupia się na terenach otwartych, takich jak zewnętrzna część kompleksu basenowego, plaża nad Wartą, trasy spacerowe w przyzamkowym parku miejskim, parki linowe, skansen etnograficzny, boiska sportowe itp. Również największe wydarzenia kulturalne (przede wszystkim koncerty muzyczne) są imprezami plenerowymi. Wydaje się więc oczywiste, że w tej sytuacji przynajmniej w ciepłej porze roku warunki opadowe mają bezpośrednie przełożenie na dynamikę ruchu turystycznego i frekwencję w atrakcjach znajdujących się na terenie Uniejowa.

Od ponad dekady na obszarze Uniejowa obserwowany jest dynamiczny wzrost liczby różnorodnych przedsięwzięć budowlanych. Powstają tu nowe obiekty mieszkaniowe, usługowe, komunikacyjne i inne. Zagospodarowaniu podlegają również przyległe do nich tereny. Skala tych inwestycji jest ogromna, biorąc pod uwagę rangę i wielkość zaludnienia tego niewielkiego przecież miasta. Wzrost zagęszczenia zabudowy, a w konsekwencji postępujące uszczelnianie podłoża gruntowego, stawia zupełnie nowe wyzwania w zakresie sposobu i technik gospodarowania wodami opadowymi. Biorąc pod uwagę aktualne warunki geomorfologiczne i hydrogeologiczne należy przyjąć, że znaczna część miasta w przypadku wystąpienia opadów o dużym natężeniu jest obecnie narażona na podtapianie (zwłaszcza równinna i nisko położona terasa po lewej stronie Warty) oraz erozję wodną (przede wszystkim krawędź doliny Warty wzdłuż jej prawego brzegu). Przy planowaniu i projektowaniu inwestycji budowlanych w tych rejonach szczególne ważne jest więc, aby obliczenia dotyczące odwodnienia tych zurbanizowanych lub urbanizujących się terenów opierać na wiarygodnych i aktualnych danych opadowych.

\section{Bibliografia}

Bank Danych Lokalnych, Główny Urząd Statystyczny, www.bdl.stat.gov.pl [dostęp: 20.04.2018].

Błażejczyk K., Szmyd J., Adamczyk A.B., Ogólne cechy potencjału leczniczego klimatu i bioklimatu Uniejowa, „Biuletyn Uniejowski” 2012, t. 1, s. 43-61.

Cebulska M., Twardosz R., Maksymalne opady dobowe w Krakowie w latach 1863-2015, [w:] Monografie Komitetu Gospodarki Wodnej PAN, red. L. Hejduk, E. Kaznowska, 2016, nr 39, s. 7-17.

Cieślukowski Z., Karpiński W., Operat uzdrowiskowy - Uzdrowisko Uniejów, Fundacja Uzdrowiska, Warszawa 2011.

Cukras M., Analiza zmienności opadów atmosferycznych $w$ rejonie Uniejowa $i$ Poddębic (woj. tódzkie), praca mgr, PD_11332_1_SD-IS-12_99405, APD UTP, Bydgoszcz 2017. 
Czarnecka M., Nidzgorska-Lencewicz J., Wieloletnia zmienność sezonowych opadów w Polsce, „Woda - Środowisko - Obszary Wiejskie” 2012, t. 12, z. 2 (38), s. 45-60.

Dąbrowski Ł., Analiza zmienności opadów atmosferycznych w rejonie Koła i Kłodawy (woj. wielkopolskie), praca mgr, PD_11333_1_SD-IS-12_99407, APD UTP, Bydgoszcz 2017.

Gąsiorek E., Musiał E., Porównanie i klasyfikacja warunków opadowych na podstawie wskaźnika standaryzowanego opadu i wskaźnika względnego opadu, „Woda - Środowisko - Obszary Wiejskie" 2011, t. 11, z. 4 (36), s. 107-119.

Guide to Meteorological Instruments and Methods of Observation (WMO - No. 8, the CIMO Guide), WMO 2014 edition, www.wmo.int [dostęp: 5.04.2018].

Kaczorowska Z., Opady w Polsce w przekroju wieloletnim, „Przegląd Geograficzny” 1962, nr 33.

Kaszewski B.M., Próba oceny zmian klimatu na Lubelszczyźnie $w$ drugiej połowie XX wieku, [w:] Klimatyczne aspekty środowiska geograficznego, red. J. Trepińska i Z. Olecki, IGiGP UJ, Kraków 2006, s. 127-138.

Kaszewski B.M., Zmiany klimatu Polski w pracach polskich klimatologów, „Przegląd Geofizyczny" 2015, nr 3-4, s. 217-235.

Kossowska-Cezak U., Martyn D., Olszewski K., Kopacz-Lembowicz M., Meteorologia i klimatologia. Pomiary, obserwacje, opracowania, Wydawnictwo Naukowe PWN, Warszawa-Lódź 2000.

Królikowska J., Królikowski A., Wody opadowe: odprowadzanie, zagospodarowanie podczyszczanie i wykorzystywanie, Wyd. Seidel-Przywecki, Warszawa 2012.

Licznar P., Rosa J., Przyczyny i sposoby zapobiegania powodziom miejskim - nowoczesny warsztat inżyniera w praktyce, „Przegląd Budowlany” 2017, nr 9, s. 34-39.

Łabęcki L., Agroclimatic determinants of irrigation needs, „Inżynieria Ekologiczna” 2016, nr 47, s. 199-204.

Majewski G., Przewoźniczuk W., Kleniewska M., Warunki opadowe na stacji meteorologicznej Ursynów SGGW w latach 1960-2009, „Przegląd Naukowy - Inżynieria i Kształtowanie Środowiska" 2010, nr 2 (48), s. 3-22.

Olechnowicz-Bobrowska B., Częstość dni z opadem w Polsce, „Prace Geograficzne” 1970, nr 86.

Radomski Cz., Agrometeorologia, Państwowe Wydawnictwo Naukowe, Warszawa 1977.

Tomaszewska T., Susze atmosferyczne na przestrzeni ostatniego czterdziestolecia, Materiały Konferencyjne. XXV Zjazd Agrometeorologów. Olsztyn-Mierki, 27-29.09.1994. Wyd. ART, Olsztyn 1994, s. 169-178.

Szyga-Pluta K., Grześkowiak K., Warunki pluwialne w Poznaniu w latach 1981-2015, Badania Fizjograficzne nad Polską Zachodnią 2016, R. VII - Seria A - Geografia Fizyczna (A67), s. 239-256.

Wałęga A., Radecki-Pawlik A., Kaczor G., Naturalne sposoby zagospodarowania wód opadowych, Wyd. UR, Kraków 2016.

Wójcik K., Treder W., Zbudniewek A., Ocena przestrzennej zmienności występowania opadów atmosferycznych w centralnej Polsce w latach 2013-2015, „Infrastruktura i Ekologia Terenów Wiejskich" 2016, nr I/1/2016, s. 73-87.

Zawora T., Ziernicka A., Precipitation variability in time in Poland in the light of multi-annual mean values (1891-2000), „Studia Geograficzne” 2003, nr 75, „Acta Universitatis Wratislaviensis", nr 2542, s. 123-128. 
Ziernicka-Wojtaszek A., Zmienność opadów atmosferycznych na obszarze Polski w latach 19712000. Klimatyczne aspekty środowiska geograficznego, IGiGP UJ, Kraków 2006.

Żmudzka E., Wspótczesne zmiany klimatu Polski, „Acta Agrophysica” 2009, nr 13(2), s. 555-568.

\title{
Strony internetowe
}

www.google.com/maps [dostęp: 5.04.2018].

[Artykuł wpłynął: maj 2018; akceptacja: czerwiec 2018]

\section{ANALYSIS OF PRECIPITATION IN UNIEJÓW AND THE RELEVANCE OF LOCAL CLIMATE STUDIES FOR A SPA TOWN}

\begin{abstract}
Summary
The article presents statistical analysis of precipitation data for the period 1980-2015 collected at the Uniejów station belonging to the Institute of Meteorology and Water Management of the National Research Institute. The analysis identified rainfall characteristics in the long term and in annual, seasonal and monthly perspective. The conducted research has shown that precipitation is one of the most variable elements of local climate, not only in terms of quantity, but also periods of their occurrence and duration. Having up-to-date knowledge of seasonal and long-term cyclicality of precipitation, as well as the possibility of significant deviations from average values, seems to be particularly important for a city whose current economic development is mainly dependent on the inflow of tourists seeking recreation and open-air entertainment. Furthermore, only a proper identification of the specific characteristics of the local climate of Uniejów provides the necessary basis for its protection against the effects of anthropogenic impact on the environment in this region.
\end{abstract}

Keywords: Uniejów, spa town, precipitation, weather conditions, mesoclimate 